Marek Kluz

Pontifical University of John Paul II in Cracow

Faculty of Theology, Section in Tarnów

\title{
Moral Calls Resulting from the Gift of the Eucharist in the Teaching of Pope Benedict XVI
}

\section{Introduction}

The sacrament of the Eucharist plays a fundamental role on the way to universal participation in God's work of salvation. The whole teaching of Benedict XVI clearly confirms this. In his post-synodal apostolic exhortation Sacramentum caritatis, the same Pope states unequivocally:

The Eucharist reveals the loving plan that guides all of salvation history (cf. Eph $1: 10 ; 3: 8-11$ ). There the Deus Trinitas, who is essentially love (cf. $1 \mathrm{Jn} 4: 7-8$ ), becomes fully a part of our human condition. In the bread and wine under whose appearances Christ gives Himself to us in the paschal meal (cf. $L k$ 22:14-20; 1 Cor 11:23-26), God's whole life encounters us and is sacramentally shared with us. [...]. The Church receives, celebrates, and adores this gift in faithful obedience. $^{2}$

${ }^{1}$ Fr Marek Kluz, PhD, Professor at PUJPII - Dean of the Faculty of Theology, Section in Tarnów, Pontifical University of John Paul II in Krakow, lecturer in moral theology. Author of several books and about 200 scientific articles on marital and family morality, moral upbringing, virtue ethics, morality of social life, bioethics, as well as social and charitable activity; e-mail: mkluz@op.pl. ORCID: 0000-0002-2255-1431.

2 Benedykt XVI, Adhortacja apostolska 'Sacramentum caritatis', Tarnów 2007, No. 8 (hereafter: SC). Also the Holy Father Francis, in his encyclical Lumen fidei, shows the Eucharist as a fundamental gift given to man who is on his way: 'The sacramental nature of faith has its highest expression in the Eucharist [...]. In the Eucharist the two axes on which faith rests are crossed. On the one hand, the axis of history: The Eucharist is an act of remembrance, an actualization of a mystery in which the past, as the event of death and resurrection, shows its capacity to open up to 
It should be emphasised that from the time of Pentecost the Church as New People began its pilgrimage to its homeland in heaven. The Sacrament of the Eucharist has become the marker of this pilgrimage, giving it the rhythm and filling it with hope, 'The Eucharist unites heaven and earth'. ${ }^{3}$ It is the sacrament which gives new life. This life is directed towards eternity. It is to strengthen man in his earthly journey.

In this perspective, since - as Benedict XVI teaches - 'The eucharistic celebration, in which we proclaim that Christ has died and risen, and will come again, is a pledge of the future glory in which our bodies too will be glorified' , ${ }^{4}$ it is an important moral task to awaken in Christians a devotion to the Eucharist. Probably, this was also the aim of the Commission on General Pastoral Care of the Polish Bishops' Conference, therefore the new three-year pastoral programme of the Church in Poland for the years 2019-2022 is focused on the mystery of the Eucharist. Eucharistic piety is the culmination of all sacramental piety. It gives the whole Christian life the Eucharistic stamp. The way to progress in the Eucharistic life is to show and fulfil in daily life the fundamental attitudes and moral demands which the gift of the Eucharist brings with it. All these demands and attitudes are expressions of the one and only love as the Eucharist grows out of love-sacrifice and love-giving.

\section{The Eucharist - Source of the Church's Life and Mission}

Before considering in detail, in the light of Benedict XVI's teaching, the fundamental attitudes which result from the gift of the Eucharist, it is first necessary to emphasise that the Eucharist is the centre of Christian life. ${ }^{5}$ The Second Vatican Council stresses that Christ, in instituting the Eucharistic Sacrifice of His Body and Blood, entrusted to the Church 'a sacrament of mercy, a sign of unity, a knot of love, a paschal meal'. ${ }^{6}$ The Council also teaches that the entire Christian life

the future, to anticipate ultimate fullness. The liturgy reminds us of this by its hodie - the 'today' of the mysteries of salvation. On the other hand, there is also an axis running from the visible to the invisible world. In the Eucharist we learn to see the depth of reality. Bread and wine are transformed into the Body and Blood of Christ, who makes Himself present on His paschal journey to the Father: this dynamic leads us with the body and soul to the journey of all creation towards its fullness in God'. Franciszek, Encyklika 'Lumen fidei', Kraków 2013, 44.

${ }^{3}$ Franciszek, Encyklika „Laudato Si'”, Kraków 2015, 236 (hereafter: LS).

${ }^{4} \mathrm{SC} 32$.

5 'The centre of the Christian life is the Eucharist: gratitude for having been gifted, joy in the new life He gives us'. Benedykt XVI, Chrześcijaństwo jest przede wszystkim darem. Homilia podczas Mszy świętej Wieczerzy Pańskiej (Watykan - 20 marca 2008), "L'Osservatore Romano" (Polish edition) 29 (2008) 5, p. 8. Cf. Benedykt XVI, Jezus z Nazaretu, cz. I: Od chrztu w Jordanie do Przemienienia, tłum. W. Szymona, Kraków 2011, p. 238.

${ }^{6}$ Sobór Watykański II, Konstytucja o liturgii świętej „,Sacrosanctum concilium” [in:] Sobór Watykański II, Konstytucje. Dekrety. Deklaracje, Poznań 2008, 47. 
and the other sacraments 'are bound up with the holy Eucharist and tend towards it. For in the most holy Eucharist the whole spiritual good of the Church is contained, namely Christ Himself, our Passover and living bread, who by His Body animated and enlivened by the Holy Spirit gives life to men, inviting and leading them to offer themselves, their work and all created things. This is why the Eucharist presents itself as the source and summit of all evangelisation'?

The Eucharist is the centre and summit of the entire sacramental life through which every Christian experiences the saving power of Redemption, beginning with the mystery of Baptism. ${ }^{8}$ In the sacrament of the Eucharist, Christ's will constantly renews the mystery of that sacrifice which He offered of Himself to the Father on the altar of the Cross, a sacrifice which the Father accepted in reciprocation with His paternal gift of new life. This new life became an effective sign of the new gift of the Holy Spirit to humanity, to all people united to Christ. The Eucharist is the most sacred sign of this union. It is a union with both earthly and heavenly Christ through the saving act of His sacrifice. The fruit of this union is divine childhood and thus incorporation into the kingdom of priests. What follows is the participation in one and only irreversible dedication of the man and the world to the Father.

The Church's current awareness of the place of the Eucharist in Christian life, was made very clear by Benedict XVI in the exhortation Sacramentum caritatis quoted above: 'The Sacrament of the Altar is always at the heart of the Church's life [...]. The more lively the Eucharistic faith of the People of God, the deeper is its sharing in ecclesial life in steadfast commitment to the mission entrusted by Christ to His disciples'. ${ }^{9}$ A similar thought from the Pope can be found in one of his general audiences: 'The Sacrament of the Body and Blood of the Lord [...] constitute the Church's most precious treasure. The Eucharist is the beating heart which gives life to the whole mystical Body of the Church. Without the Eucharist the Church would simply not exist'.${ }^{10}$ Therefore, the Eucharist constitutes the existence and activity of the Church.

It is not surprising, then, that the Church lives the Eucharist, lives the fullness of this sacrament, but at the same time the Church's teaching is not capable of

${ }^{7}$ Sobór Watykański II, Dekret o postudze i życiu prezbiterów „,Presbyterorum ordinis” [in:] Sobór Watykański II, Konstytucje..., 5.

${ }^{8}$ Cf. SC 17.

${ }^{9}$ Ibid. 6-8. Cf. more: J. Ratzinger, Teologia liturgii. Sakramentalne podstawy życia chrześcijańskiego. Opera omnia, vol. XI, thum. W. Szymona, Lublin 2012, pp. 287-337. Cf. also: A. Sylwanowicz, Eucharystia w teologii liturgii Benedykta XVI, "Studia Loviciensia" 15 (2013), p. 93.

${ }^{10}$ Benedykt XVI, Święto Eucharystii, bez której Kościół nie może istnieć. Rozważanie przed modlitwą „Anioł Pański” (Watykan - 26 czerwca 2011), “L'Osservatore Romano” (Polish edition) 32 (2011) 8-9, p. 49. Cf. id., Eucharystia skarbem Kościoła. Rozważanie przed modlitwa „Aniot Pański” (Castel Gandolfo - 4 września 2005), "L’Osservatore Romano” (Polish edition) 26 (2005) 10, p. 50; id., List apostolski „Porta fidei”, Kraków 2012, 9; id., Jezus z Nazaretu, cz. II: Od wjazdu do Jerozolimy do Zmartwychwstania, thum. W. Szymona, Kielce 2011, p. 151. 
fully embracing and expressing all that constitutes, expresses and accomplishes it. ${ }^{11}$ From all this follows the fundamental task of all the baptized to grow spiritually in the climate of the Eucharist, as Pope Benedict points out:

The Eucharist, as the source and summit of the Church's life and mission, must be translated into spirituality, into a life lived 'according to the Spirit' [...]. the Christian laity, by virtue of their Baptism and Confirmation, and strengthened by the Eucharist, are called to live the radical newness brought by Christ wherever they find themselves. They should cultivate a desire that the Eucharist has an ever deeper effect on their daily lives, making them convincing witnesses in the workplace and in society at large. ${ }^{12}$

The Eucharist, therefore, indicates not only the need to fulfil certain duties of Eucharistic participation, but above all to imbue one's whole life with all that the mystery of the Eucharist entails.

At this point we should first realise that it is extremely important for Eucharistic formation to link catechisation with participation in the Holy Mass. A painful phenomenon is the growing percentage of children and youth who attend catecheses but do not participate in Sunday Mass. This should be particularly emphasised today, when catechisation takes place at school and identification with the parish community as the Eucharistic community (catechesis is not of a parish character) is hindered. The demand for a close connection between catechisation and the Eucharistic celebration has its formal dimension, i.e. seeking ways to connect catechesis and Mass (for example, Masses for individual classes at least once a semester), but also a substantive dimension, namely catechesis should constantly refer to the Eucharist, show it as the centre of Christian life, show its ecclesial dimension making the Church present and building it up in and through the Eucharist. ${ }^{13}$

\section{The Eucharist - the Sacrifice of Christ and the Church. A Call to a Sacrificial Attitude}

In the teaching of Benedict XVI, 'the Eucharist is the memorial of Christ's sacrifice on the Cross'. ${ }^{14}$ In the Eucharist, Jesus gives not 'something' but Himself;

${ }^{11}$ Cf. J. Szymik, Theologia Benedicta, vol. 2, Katowice 2016, p. 257.

12 SC 77-79.

${ }^{13}$ Cf. ibid., 64, 67.

${ }^{14}$ Benedykt XVI, Niech Kongres będzie dla was owocnym doświadczeniem komunii z Chrystusem. Przestanie na 50. Międzynarodowy Kongres Eucharystyczny w Dublinie (Watykan 17 czerwca 2012), "L’Osservatore Romano" (Polish edition) 33 (2012) 7-8, p. 41. Cf. id., Krzyż Chrystusa przemienił kult starotestamentalny (Św. Paweł a kult sprawowany przez chrześcijan). 
He offers His body and sheds His blood. In the Eucharist, then, the sacrifice of Christ is continually repeated. Since the Eucharist is called a sacrifice, the fundamental moral call of this sacrament is that of a life-long sacrificial attitude. This sacrificial attitude should be realised above all in the mission of bringing Christ the Saviour to the world. Benedict XVI makes us aware that

the Eucharist, as the sacrament of our salvation, inevitably reminds us of the unity of Christ and the salvation that He won for us by His blood. The mystery of the Eucharist, believed in and celebrated, demands a constant catechesis, the central element on the need for all to engage in a missionary effort centred on the proclamation of Jesus as the one Saviour. ${ }^{15}$

Christ is the only Saviour 'and there is salvation in no other, for no other name under heaven has been given to men by which we can be saved' (Acts 4:12). Christ makes this work of salvation present above all in the Eucharist, which is an action of both Christ and the Church. ${ }^{16}$

It is important to stress that the Eucharist is first of all the sacrifice of Christ as Priest, "who gives Himself to us, building us up continually as His body'. ${ }^{17}$ In instituting this Sacrament, Christ pointed to Himself as a Priest giving Himself in death and thus offering Himself as sacrifice (Lk 22:19-20). ${ }^{18}$ Pope Benedict XVI explains this truth in the following words: 'In instituting the sacrament of the Eucharist, Jesus anticipates and makes present the sacrifice of the Cross and the victory of the resurrection. At the same time, He reveals that He Himself is the true sacrificial lamb, destined in the Father's plan from the foundation of the world'. ${ }^{19}$ The gift Jesus made is first of all a gift to his Father.

Audiencja generalna (Watykan - 7 stycznia 2009), "L'Osservatore Romano" (Polish edition) 30 (2009) 3, p. 34; id., Eucharystia największym naszym darem. Przemówienie do przedstawicieli środowisk akademickich Rzymu (Watykan - 14 grudnia 2006), "L’Osservatore Romano" (Polish edition) 28 (2007) 2, p. 37.

${ }^{15}$ SC 86. Cf. Benedykt XVI, Zmartwychwstaty Chrystus idzie pośród nas. Homilia podczas Mszy świętej w uroczystość Bożego Ciała (Watykan — 23 czerwca 2011), "L'Osservatore Romano" (Polish edition) 32 (2011) 8-9, p. 32.

${ }^{16}$ Cf. M. Antoniewicz, Chrystologiczno-sakramentalne podstawy „mistyki” Eucharystii w „Deus caritas est” Benedykta XVI, "Poznańskie Studia Teologiczne” 23 (2009), pp. 107-113.

17 SC 14. Cf. Papieska Komisja Teologiczna, Biblia a moralność. Biblijne korzenie postepowania chrześcijańskiego, thum. R. Rubinkiewicz, Kielce 2009, pp. 106-113.

${ }^{18}$ Cf. Benedykt XVI, Odnówmy wiarę w rzeczywista obecność Chrystusa w Eucharystii. Homilia podczas Mszy świętej w uroczystość Najświętszego Ciała i Krwi Pańskiej (Watykan 11 czerwca 2009), "L’Osservatore Romano" (Polish edition) 30 (2009) 10, p. 10. Cf. also: id., Celebrując Eucharystię, kapłani torują drogę modlitwie wspótczesnych ludzi. Homilia podczas Mszy świętej Krzyżma w Wielki Czwartek (Watykan - 9 kwietnia 2009), "L’Osservatore Romano" (Polish edition) 30 (2009) 6, p. 20.

${ }^{19}$ SC 10. 
However, in the Eucharist - as on the Cross - Christ not only offered Himself to the Father, but with Himself offered the whole Church as its Head. Benedict XVI reminds us of this in Sacramentum caritatis, 'Catholic doctrine, in fact, affirms that the Eucharist, as the sacrifice of Christ, is also the sacrifice of the Church and thus of all the faithful' ${ }^{20}$ In giving His sacrifice to the Church, Christ also wished to accept the Church as His spiritual sacrifice, which is called upon to offer itself in the sacrifice of Christ. Thus, the Church is obliged to offer itself to God in union with the sacrifice of Christ. In the Eucharistic sacrifice the universal priesthood of the faithful thus finds its special place and its deepest application. By fulfilling their priesthood and offering themselves in the Eucharistic sacrifice together with the whole Church, Christians join themselves to the one and only sacrifice of Christ and thus participate in the most perfect way in the fruits of Christ's sacrifice, as Pope Benedict XVI carefully instructs: 'The Eucharist draws us into Jesus' act of self-oblation. More than just statically receiving the incarnate Logos, we enter into the very dynamic of His self-giving. Jesus "draws us into Himself". ${ }^{21}$

The Eucharist makes it abundantly clear that the sacrifice of the Christian must be linked to the sacrifice of Christ and made in imitation of Him: 'Be imitators of God, as beloved children, and walk in the way of love, for Christ also loved you and gave Himself for you as a sacrifice and as a gift of thanksgiving to God' (Eph 5:1-2). Christ offers Himself to His Father through our bodies and our lives. It is Christ Himself who offers us to God, and we offer Him to God. There is no other sacrifice than His sacrifice and no other love than His love. ${ }^{22}$

Since the Eucharistic sacrifice is sacrifice of Christ and of the Church, and since in the Church we are members of one another, it is obvious that the Christian who offers himself in imitation of Christ does so and must do so not only for himself but also for those who are his brothers and sisters in Christ. The Christian, therefore, has not only the right but directly the duty to offer himself, his life and spiritual gifts for others. 'By sharing in the sacrifice of the Cross', Benedict XVI makes clear, 'the Christian partakes of Christ's self-giving love and is equipped and committed to live this same charity in all His thoughts and deeds' ${ }^{23}$ From this

${ }^{20}$ Ibid. 70. Cf. Benedykt XVI, Eucharystia otwarta na wszystkich jest prawdziwym miejscem jedności. Przemówienie do wspólnoty Drogi Neokatechumenalnej (Watykan — 20 stycznia 2012), "L'Osservatore Romano" (Polish edition) 33 (2012) 3, p. 18.

${ }^{21}$ SC 11. Por. Benedykt XVI, Eucharystia musi być centrum waszego życia. Homilia podczas Mszy świętej na zakończenie Światowego Dnia Młodzieży (Watykan — 21 sierpnia 2005), "L'Osservatore Romano" (Polish edition) 26 (2005) 10, pp. 26-27; id., Encyklika „Deus caritas est”, Kraków 2006, 228 (hereafter: DCE); K. Jeżyna, Eucharystia [in:] Jan Paweł II, Encyklopedia nauczania moralnego, red. J. Nagórny, K. Jeżyna, Radom 2005, p. 190.

${ }^{22}$ Cf. A. Michalik, Zrozumieć chrześcijaństwo. Istota chrześcijaństwa wedlug Josepha Ratzingera, Tarnów 2008, p. 253.

${ }^{23} \mathrm{SC} 82$. 
it follows that every act of love can be an act of sacrifice. The Eucharist that does not translate into concretely practised love would itself be fragmentary. ${ }^{24}$

Committed participation in the celebration is also the source of the moral transformation of the human heart, which becomes the dwelling place of God. In Benedict XVI's understanding, the moral transformation contained in the Eucharistic cult is 'a heartfelt yearning to respond to the Lord's love with one's whole being, while remaining ever conscious of one's own weakness'.$^{25}$ This transformation of the human heart is not the fruit of the human effort but of divine action. But not without significance is the attitude of will, which has to be expressed by readiness to give one's heart to the Saviour, who has the power to change it. The Eucharist, in which the transformation of the human heart takes place, plays an important role on the path of perfecting love. This path is connected with human effort and hardship. Human effort will be fruitful when it is supported by God's action. From this it clearly results that it is the man's duty to feed on the Body of the Lord.

\section{The Eucharist — a Sacrificial Meal. A Call to Feed on the Bread of Life}

The Eucharist calls every Christian to feed on the Bread of Life, that is, to a sacrificial meal. The aspect of the Eucharist as a feast was highlighted by Benedict XVI during his homily on the Solemnity of Corpus Christi on June 23, 2011: 'The fact that the Sacrament of the Altar has taken the name 'Eucharist' - 'thanksgiving' expresses precisely this: that the transubstantiation of bread and wine into the Body and Blood of Christ is the fruit of the gift that Christ made of Himself - the gift of love stronger than death, divine love that made Him rise from the dead. This is why the Eucharist is the food of eternal life, the Bread of Life [...]. Beautiful and very eloquent is the expression 'to receive communion' to describe the act of eating the Eucharistic Bread. In fact, when we do this act, we enter into communion with the life of Jesus Himself, we enter into the dynamics of that life which becomes a gift to us and for us. From God, through Jesus, to us - the only communion is communicated in the Holy Eucharist. ${ }^{26}$ And so the Mass is the sacred feast of communion in the Body and Blood of the Lord. The celebration of the Eucharistic

${ }^{24}$ Cf. ibid. 82. Cf. also: DCE 229; A. Wojtczak, Spoteczne konsekwencje Eucharystii wedtug adhortacji apostolskiej Benedykta XVI ,, Sacramentum caritatis”, "Liturgia Sacra” 13 (2007) 1, p. 73.

${ }^{25}$ SC 82. Por. Benedykt XVI, Światłość świata. W rozmowie z Peterem Seewaldem, thum. P. Napiwodzki, Kraków 2011, p. 165.

${ }^{26}$ Benedykt XVI, Zmartwychwstaty Chrystus..., p. 31. Cf. id., Adhortacja apostolska „,Verbum Domini”, Kraków 2010 54; id., Nasze drogi niech będa drogami Jezusa. Homilia podczas Mszy świętej w uroczystość Najświętszego Ciała i Krwi Chrystusa (Watykan — 26 maja 2005), "L'Osservatore Romano" (Polish edition) 26 (2005) 7-8, p. 24. 
Sacrifice is oriented towards the interior union of the faithful with Christ through Communion. To receive Holy Communion is to receive Christ who offered Himself for mankind. ${ }^{27}$

Before His passion and death, Jesus longed to eat a Passover meal (Lk 22:15). It was also supposed to be a farewell before His departure for heaven. Through this Meal — as the Risen Lord - He remained among us, celebrates His sacrifice with us and shares our Passover with us. This 'meal' with God is a sign of special intimacy and confirmation of unity, a sign of the Covenant. ${ }^{28}$ This context the context of the sacrificial meal - allows us to understand more deeply the purpose of Eucharistic devotion. It is to express love and sanctifying closeness of the One who died for us. Love crucified turns to each person in a particularly personal way. If, therefore, we participate properly in the meal and sacrifice of Christ and open ourselves freely to His love for us, that love will become in us and through us a salvific event for the world. ${ }^{29}$

Hence, the main moral obligation for Christians as participants at the Eucharistic meal is to seek the fullest possible personal union with Christ in Holy Communion, so that His saving love may work in us and through us. Here the perspective of the New Covenant, which emphasises the personal character of the relationship between God and people and between people and God, is of great help. Union under the New Covenant has the character of mutual immanence: God participates in our life and we in His life. ${ }^{30}$ In this context, the reception of Holy Communion generates an awareness of Christ's presence in our lives on a daily basis, and not just an awareness of being given 'some' gifts. By receiving the Eucharist, the faithful draw life from it and with it the victorious power of Christ's death. Consuming the Body and Blood of the Lord thus leads Christians into experiencing the death of Christ. This is already clearly stated by St. Paul, 'For as often as you eat this bread, or drink from the one cup, you proclaim the Lord's death until

${ }^{27}$ Cf. A. Żurek, ,Mysterium passionis — corpus et sanguis Christi - communio”. Eucharystia sakramentem wtajemniczenia chrześcijańskiego w Kościele tacińskim czwartego i początku piatego wieku, Katowice 2012, pp. 230-237.

${ }_{28}^{28}$ Cf. Benedykt XVI, Pawet Apostot Narodów, Częstochowa 2008, pp. 83-91.

29 In the apostolic exhortation Sacramentum caritatis, Benedict XVI stresses that 'on the journey to the Father, communion in the Body and Blood of Christ appears as the seed of eternal life and the power of resurrection' (No. 22). Cf. Benedykt XVI, Encyklika ,Spe salvi”, Tarnów 2007, 48; id., Chleb, który prawdziwie zaspokaja głód człowieka. Rozważanie przed modlitwa „Aniot Pański" (Castel Gandolfo - 29 lipca 2012), "L’Osservatore Romano" (Polish edition) 33 (2012) 9-10, pp. 49-50; id., Chrystus Głowa Ciała - Kościoła i władca wszechświata (Św. Paweł a Kościół Chrystusowy). Audiencja generalna (Watykan - 14 stycznia 2009), "L’Osservatore Romano" (Polish edition) 30 (2009) 3, p. 36; id., Dar komunii. Audiencja generalna (Watykan 29 marca 2006), "L'Osservatore Romano" (Polish edition) 27 (2006) 8, p. 36.

${ }^{30}$ Cf. W. Bołoz, Moralne zobowiązanie Eucharystii "Homo Dei" 55 (1986) 1, pp. 176-179. 
He comes' (1 Cor 11:26). ${ }^{31}$ Receiving the Body and Blood of the Lord is thus a call to become ever more like Christ, both as Priest and as Victim.

While stressing the importance of 'communion' piety however, we should not conclude from this that Mass without Holy Communion is worthless, since it is always directed towards the future full Eucharistic union in one's life. Consequently, encouraging full participation in Mass must not mean some kind of compulsion on the part of people, since this could lead to sacrilegious Communion. A prudent approach to this problem is also related to the fact that today many Catholics are hindered from participating fully in the Mass, and at the same time they should be encouraged not to give up their very participation in the Eucharist. Benedict XVI makes it clear that 'even in cases where it is not possible to receive sacramental Communion, participation at Mass remains necessary, important, meaningful and fruitful. In such circumstances, it is beneficial to cultivate a desire for full union with Christ through the practice of spiritual communion, praised by Pope John Paul II and recommended by saints who were masters of the spiritual life'. ${ }^{32}$

\section{Eucharist - Thanksgiving and Praise. A Call to an Attitude of Thanksgiving and Praise}

In the teaching of Benedict XVI, the Eucharist, like sacrifice of the Cross, is not only sacrifice of atonement for our sins, but it is also sacrifice of thanksgiving to the Father and adoration, through which the Church expresses its gratitude to God for all the good things He has done..$^{33}$ The very act of Christ's sacrifice contains the truth of thanksgiving Jesus offers to the Father. 'Christ - Benedict explains in a catechesis - gave his life surrounded by hatred and hypocrisy, yet He transformed this passion - and thus also the circumstances surrounding it — into the Eucharist: into a feast of thanksgiving. The Eucharist is thanksgiving, 'I will lift up the cup of salvation'. ${ }^{34}$ Every Christian, through his or her participation in

${ }^{31}$ Cf. Benedykt XVI, Żyjmy moca Eucharystii. Homilia podczas Mszy świętej z okazji inauguracji Synodu (Watykan — 2 października 2005), "L’Osservatore Romano" (Polish edition) 27 (2006) 1, p. 8. Cf. also: id., Pan Jezus idzie ulicami Rzymu. Homilia podczas Mszy świętej w uroczystość Najświętszego Ciała i Krwi Chrystusa (Watykan - 7 czerwca 2007), "L'Osservatore Romano" (Polish edition) 28 (2007) 7-8, p. 40.

${ }^{32} \mathrm{SC} 55$.

${ }^{33}$ Por. Benedykt XVI, Pokarm, który wzmacnia zmęczonych i zagubionych. Audiencja generalna (Watykan — 11 stycznia 2012), "L'Osservatore Romano" (Polish edition) 33 (2012) 3, pp. 30-31.

${ }^{34}$ Id., Psalm 116 b - dziękczynienie w światyni. Audiencja generalna (Watykan — 25 maja 2005), "L'Osservatore Romano" (Polish edition) 26 (2005) 7-8, p. 29. 
Eucharistic sacrifice, joins in this act of thanksgiving of Christ. The point, however, is that this Eucharistic act should be extended throughout the Christian life. ${ }^{35}$

An attitude of gratitude to God, thanking Him for all His benefits, is not just a verbal expression of one's inner feelings, but must be expressed in a certain attitude of life. At the outset, it is a matter of accepting these blessings with one's whole heart, that is, fully accepting the fact of the gift. Only then does thanksgiving also mean reciprocating for these gifts by faithfully observing God's requirements, by zealously fulfilling His commandments. Hence, to give thanks to God is to contribute with one's whole life to the daily fulfilment of God's saving plan, 'Alleluia. Praise the Lord, for He is good, for His mercy is everlasting. Who will tell of the works of the Lord's power, who will proclaim all His praises? Happy are those who keep the commandments, who at all times do what is right' (Ps 106:1-3).

Thanksgiving to the Father through the Son reached its peak when the Son completed the work of salvation by 'becoming obedient unto death, and that death on the cross' (Phil 2:8). Christ makes these salvific benefits present in the Eucharist, at the same time entrusting them to the Church. Everyone, therefore, who belongs to the Church must give thanks to God for them, not only on solemn occasions, but always, every day, in every action, 'In every circumstance give thanks, for this is the will of God in Christ Jesus for you' (1 Th 5:17). Everyone who maintains this attitude of thanksgiving releases in himself the capacity for admiration, trust and love for God and brothers. The particular moment of this thanksgiving is participation in the sacrifice of Christ and the Church, which is why it from the very beginning it was called Eucharist - thanksgiving. The Christian life is thus great thanksgiving, and its summit is found in the Eucharist.

It must be added that thanksgiving cannot be separated from sacrifice, since true gratitude to God is expressed in the obedient, sacrificial, loving offering of one's life to God in the service of salvation. According to Benedict XVI, the sincere celebration of the Eucharist must be linked to service:

Each celebration of the Eucharist makes sacramentally present the gift that the crucified Lord made His life by His death on the Cross for us and for the whole world. In the Eucharist Jesus also makes us witnesses of God's compassion towards all our brothers and sisters. The Eucharistic mystery thus gives rise to a service of charity towards our neighbour. ${ }^{36}$

The Eucharist therefore urges every believer to become 'broken bread' for others. In this way the good received in the Eucharist, 'abounding in the gratitude of many, is multiplied to the glory of God' (2 Cor 4:15).

${ }^{35}$ Cf. Jan Paweł II, Encyklika „Ecclesia de Eucharistia”, Tarnów 2003, 58.

${ }^{36} \mathrm{SC} 88$. 
Thanksgiving has its communal dimension. Where people are able to give thanks to God together, and at the same time to give thanks for each other and for themselves, there human community is deepened and perfected. The Eucharist is thus a place of thanksgiving for everything - with everyone - for everyone. Simultaneously, the Eucharist calls for this ability to give thanks to be a part of our daily relationships with our neighbours. ${ }^{37}$ For this to happen, an important educational task is to instil an attitude of gratitude from a very young age. If children do not have to give thanks for anything, because they think that everything is their parents' duty, they will not learn to experience the Eucharist properly since the Eucharist is thanksgiving. The child must feel a sense of gratitude, then the child will understand that one should give thanks to God and to people.

The Eucharist is also sacrifice of praise through which the Church proclaims the glory of God on behalf of all creation. As Benedict XVI explains 'already in the words of the Psalmist, 'I will lift up the cup of salvation and call upon the name of the Lord', the tradition of the Church sees the prefiguration of the Eucharist, sacrifice of love and praise'. ${ }^{38}$ 'The sacrifice of praise is possible only through Christ, who unites the faithful to His person and to His praise and intercession. In this way the sacrifice of praise is offered to the Father through Christ and with Christ, so that it may be accepted in Him'.${ }^{39}$ So, by experiencing goodness, man awakens in himself not only a sense of gratitude, but also an attitude of awe and adoration. St John Paul states that 'the Eucharist has been given to us so that our whole life $[\ldots]$ may be one "Magnificat"!'. ${ }^{40}$

The duty to glorify God comes from the fact that Christ Himself glorified God and blessed Him for all His actions (Mt 14:19; 15:36; Mk 8:7; Jn 6:11; 6:23), and before His death, He asked — blessing the Father for the whole work of salvation - that His humanity be given the glory which He had with the Father 'before the world was made' (J 17:5). The Father listened to the Son (Phil 2:9-11), and the Son, having immortalized all this in the Eucharist, has given us the possibility of giving glory to the Father. Hence - as Pope Francis underlines in his encyclical Laudato Si' - 'the whole universe, united to the Son Incarnate, present in the Eucharist, gives glory to God'. ${ }^{41}$

In the practice of Christian life, Eucharistic devotion, directed towards the praise of God, finds its fulfilment also outside participation in Holy Mass. It is

${ }^{37}$ Cf. A.J. Nowak, Eucharystia znaczy dziękczynienie [in:] Eucharystia - miłość i dziękczynienie. Homo meditans IX, red. W. Słomka, A.J. Nowak, Lublin 1992, pp. 53-74. Cf also: J. Nagórny, Eucharystia - we wspólnocie i dla wspólnoty [in:] Eucharystia - miłość i dziękczynienie..., pp. 138-139.

${ }^{38}$ Benedykt XVI, Psalm 116 b..., p. 29.

39 Katechizm Kościoła Katolickiego, Poznań 1994, 1361.

40 Jan Paweł II, Encyklika Ecclesia..., 58.

${ }^{41}$ Franciszek, Encyklika Laudato..., 236. 
connected with various forms of adoration, worship of the Blessed Sacrament, services such as exposition of the Blessed Sacrament, blessing with the Blessed Sacrament, Eucharistic processions, including the Corpus Christi procession. These and many other forms of Eucharistic devotion are mentioned and encouraged by Pope Benedict XVI:

Besides encouraging individual believers to make time for personal prayer before the Sacrament of the Altar, I feel obliged to urge parishes and other Church groups to set aside times for collective adoration. Naturally, already existing forms of Eucharistic piety retain their full value. I am thinking, for example, of processions with the Blessed Sacrament, especially the traditional procession of the Solemnity of Corpus Christi, the Forty Hours devotion, local, national and international Eucharistic Congresses, and other similar initiatives. If suitably updated and adapted to local circumstances, these forms of devotion are still worthy of being practised today. ${ }^{42}$

All these elements of Eucharistic devotion, directed towards praise of God and thanksgiving for the gift of His presence and all the other gifts in the way of salvation, are also a very important way of personal and communal sanctification. This is why Benedict XVI proposes that 'in the catechetical training, especially in the preparation for First Holy Communion, children should be taught the meaning and the beauty of spending time with Jesus, and helped to cultivate a sense of awe before his presence in the Eucharist'. ${ }^{43}$

\section{The Eucharist - a Mystery of Faith and Love. A Call to Faith and Love}

The Eucharist also calls the Christian to faith and love, and this is because it is often referred to as the Mystery of Faith and the Sacrament of Love. Christ preceded His promise of the 'bread of life' with a call to faith (Jn 6:26-40). The gift of divine life results from the gift of faith, but at the same time it finds its profound expression in the gift of the Eucharist and therefore, it is mysterium fidei, as the priest reminds us at the central point of the Mass by exclaiming, 'Behold the great mystery of faith'. 'Indeed - Benedict XVI says - the Eucharist is, in the whole sense of the word, "the mystery of faith", "the summary and summary of

${ }^{42}$ SC 68. Cf. Benedykt XVI, Pochylmy się przed Bogiem, który pochylit się nad nami. Homilia podczas Mszy świętej w uroczystość Bożego Ciała (Watykan — 22 maja 2008), "L'Osservatore Romano" (Polish edition) 29 (2008) 6, pp. 48-50.

${ }^{43} \mathrm{SC} 67$. 
our faith". The Church's faith is essentially a Eucharistic faith, and it is especially nourished at the table of the Eucharist'. ${ }^{44}$

There is a deep sense in which Christ wanted to remain present in His Church in this unique way. Since He was to leave His brothers in a visible form, $\mathrm{He}$ wanted to give us His sacramental presence; since He was to offer Himself on the cross for our salvation, He wanted us to have a memorial of His love with which He loved us 'to the end' (Jn 13:1), right down to the gift of His life. Indeed, while present in the Eucharist, He remains mysteriously present among us as the one who loved us and gave Himself for us. He remains present under the signs which express and communicate this love: the Church and the world have a great need of Eucharistic worship. Christians should therefore not deny Christ the time to go and meet Him in adoration, in contemplation full of faith, open to making reparation for the grave faults and transgressions of the world. ${ }^{45}$

In this context, the role of participation in the Mass in awakening and developing faith needs to be very clearly underlined. If this participation is simple, open to Christ and full of joy, it can revitalise faith, even in the weak and astray ones. But revival of faith, and sometimes outright conversion, also depends on the authenticity of the celebration of the Eucharist. At times, therefore, an unspiritual celebration of the Eucharist and participation in it in the same way can become (especially for the weak in the faith) a serious threat to the development of faith.

The faith expressed in the Eucharist should then be expressed in concrete forms of life. For the profession of faith in the Eucharistic celebration is credible if it is in harmony with the whole of life lived in faith. Christian faith requires unity between the Eucharistic celebration and life. Hence the mystery of faith in which believers participate calls for meditative, loving reflection on the meaning of what they are participating in. Since the faith of every believer is marked by weakness and our sins, in the celebration of the Eucharist we refer to the faith of the Church, which is something permanent. ${ }^{46}$

According to Benedict XVI, the Eucharist is also a great gift of love and a call to love. The Eucharist not only bears witness to the One who 'loved us to the

${ }^{44}$ Ibid., 6. Por. Benedykt XVI, Adoracja najlepszym przygotowaniem do komunii eucharystycznej. Przemówienie do uczestników sesji plenarnej Kongregacji ds. Kultu Bożego i Dyscypliny Sakramentów (Watykan - 13 marca 2009), "L'Osservatore Romano" (Polish edition) 30 (2009) 5, p. 49. Cf. also: W. Pałęcki, Eucharystia w świetle teologii misteriów i posynodalnej adhortacji „, Sacramentum caritatis” papieża Benedykta XVI, "Liturgia Sacra” 14 (2008) 2, pp. 344-346.

${ }^{45}$ Cf. more: Jan Paweł II, List apostolski „Dominicae coenae” [in:] Wybór listów Ojca Świętego Jana Pawła II, vol. 1, Kraków 1997, pp. 3-30.

${ }^{46}$ Cf. J. Charytański, Eucharystia centrum życia chrześcijańskiego, "Ateneum Kapłańskie" 75 (1983), vol. 101, pp. 392-397. 
end'. The Eucharist educates to such love. ${ }^{47}$ Thanks to an attitude of love, the Eucharist becomes an act of worship and adoration. The Eucharist is also "the visible unity of all [...], it is the sacrament of unity. It even touches the Trinitarian mystery and thus creates at the same time a visible unity' ${ }^{48}$ The Eucharist is a sign of the special unity of God with men and of men with God, which finds its extension in unity among men. Consequently, participation in the Eucharist is a great school of love and unity, and these attitudes should permeate the whole of Christian life. ${ }^{49}$

The building of unity is connected with sacrifice, with breaking with sin, which in a particular way destroys that unity and hinders its building. ${ }^{50}$ The Eucharist, as the source of the Church's unity, results in communion and sacramental brotherhood. Through the Eucharist Christians find their identity. Christian identity includes unity with God and brothers. The Eucharist, by uniting us with God, simultaneously generates unity with other people. ${ }^{51}$ It demands at the same time openness to everything that Christ offers and that one can receive from another person. 'It is clear - says Benedict XVI — that we cannot be in communion with the Lord if we are not in communion with one another. If we want to stand before Him, we must also go out to meet one another'. ${ }^{52}$ The Eucharist thus becomes a model in the formation of an attitude of sacrificial love. Participation in the Eucharist is a pledge of the resurrection which opens up the prospect of full communion with God in eternal life..$^{53}$

${ }^{47}$ Cf. Benedykt XVI, Eucharystia szkoła miłości i solidarności. Rozważanie przed modlitwa „Aniot Pański" (Watykan - 25 maja 2008), "L'Osservatore Romano" (Polish edition) 29 (2008) 7-8, p. 42; id., „Sacramentum caritatis” źródlem radości chrześcijańskiej. Rozważanie przed modlitwa ,Anioł Pański” (Watykan — 18 marca 2007), "L'Osservatore Romano” (Polish edition) 28 (2007) 5, pp. 54-55.

${ }^{48}$ Id., Eucharystia jest tajemnica wielkiej bliskości i komunii każdego człowieka z Panem. Homilia podczas mszy świętej Wieczerzy Pańskiej (Watykan — 21 kwietnia 2011), "L’Osservatore Romano" (Polish edition) 32 (2011) 6, p. 35.

${ }^{49}$ Cf. A. Perz, Wplyw Eucharystii na życie chrześcijanina, "Kieleckie Studia Teologiczne" 5 (2006), pp. 130-132.

${ }^{50}$ Benedykt XVI, Encyklika „Caritas in veritate”, Tarnów 2009, 34.

51 'Christ and neighbour', Benedict XVI said in a general audience, 'are inseparable in the Eucharist. And so we are all one bread, one body. The Eucharist without solidarity with others is an abuse of the Eucharist'. Benedict XVI, The Church is an organism, not an organisation (St Paul and the Sacraments). General Audience (Vatican City - 10 December 2008), "L'Osservatore Romano" (English edition) 30 (2009) 2, p. 51.

${ }^{52}$ Id., W Eucharystii Chrystus żyje wśród nas i dla nas. Homilia podczas Mszy świętej na zakończenie XXIV Kongresu Eucharystycznego we Włoszech (Bari — 29 maja 2005), "L'Osservatore Romano" (Polish edition) 26 (2005) 9, p. 10.

${ }_{53}$ Por. S. Suwiński, Wychowanie dziecka do życia Eucharystia, "Ateneum Kapłańskie" 584 (2006) 147 , pp. 70-71. 
The Eucharist is a constant invitation to seek unity in the ways of love, for, as Benedict XVI teaches, 'it is the mystery of the covenant'. ${ }^{54}$ This covenant in Christ is the foundation not only of unity with God, but also of unity among people. Through the gift of the Body and Blood of the Lord, new People of God are born, people united by love and sacrifice of Christ Himself. The Eucharist aims to strengthen the unity which flows from love, the love which led Christ to pour out His Blood for people. In the Eucharist the new and everlasting Covenant between Christ and the Church is expressed. The Christian's vocation, therefore, is 'to enter into this mystery of the Covenant by conforming his or her life ever more closely every day to the gift received in the Eucharist' ${ }^{35}$ Everyone who joins in this Covenant simultaneously joins in the unity and love of the people of the Covenant.

The attitude of unity and charity in the Eucharistic celebration, although intrinsically interior, must also be expressed outwardly and thus become a clear sign to the world. Benedict XVI highlighted this aspect in his homily at the conclusion of the Eucharistic Congress in Italy on May 29, 2005:

The Eucharist - let us repeat it — is the sacrament of unity. But Christians are, unfortunately, divided, and they are divided precisely in the sacrament of unity. This makes it all the more necessary for us, supported by the Eucharist, to feel urged to strive with all our strength for that full unity for which Christ earnestly asked in the Upper Room. ${ }^{56}$

Christ, in the Eucharistic liturgy, constantly reminds us of the price He paid for our unity, and therefore calls Christians to an attitude of sacrifice on behalf of unity. Without sacrifice, without self-denial, it is impossible to be truly and fully at the service of unity. The Eucharistic meal is closely linked to an attitude of service, an attitude of washing feet, that is, an attitude of humble readiness to serve others. It is only with this attitude that the Eucharist becomes a source of strength and a school of life for every Christian. ${ }^{57}$

${ }^{54}$ Benedykt XVI, Eucharystia darem Boga dla życia świata. Homilia podczas Mszy świętej na zakończenie 49. Międzynarodowego Kongresu Eucharystycznego w Quebecu (Watykan 22 czerwca 2008), "L'Osservatore Romano" (Polish edition) 29 (2008) 7-8, p. 24.

55 Ibid., p. 24.

${ }^{56}$ Id., W Eucharystii..., p. 10. Por. id., Eucharystia otwarta ..., pp. 17-18.

${ }^{57}$ Cf. id., Eucharystia i miłość. Rozważanie przed modlitwa „Anioł Pański” (Watykan — 25 września 2005), "L’Osservatore Romano” (Polish edition) 27 (2006) 1, pp. 55-56. 


\section{Conclusions}

The above reflection, based on the teaching of Benedict XVI, makes it clear that the Eucharist is one of the most important sacraments in the Catholic Church. The Church lives thanks to it. This is truth which expresses not only the experience and life of faith itself, but above all contains the sense and mystery of the Church. In the sacrament of the Eucharist, at the moment of the transubstantiation of bread and wine into the Body and Blood of Jesus Christ, the Church is especially animated by the presence of God Himself.

The sacrament of the Eucharist is also indispensable for shaping and developing the Christian life. The Church offers man the inestimable gift of the Eucharist, which is the centre of the whole moral life of Christians. The Most Holy Sacrifice is a gift of love of God wishing to remain with people under the cover of bread. It makes present the one and only sacrifice of the Cross made by Christ for all humanity on Calvary. The tree of the cross, on which redemption was accomplished, became the source from which all graces will be given to people until the end of time. The use of this source is made possible by the Eucharist, during which Christ descends on the altar. Participation in this sacrifice, combined with awareness of these great mysteries which are being accomplished, gives rise to specific moral obligations whose fulfilment leads man to holiness. The sacrament of the Eucharist is thus the most precious gift that Jesus has left to man.

\section{Wezwania moralne płynące z daru Eucharystii w nauczaniu papieża Benedykta XVI}

\section{Streszczenie}

Rola Eucharystii w kształtowaniu życia moralnego jest przeogromna i właściwie dzięki Eucharystii można odczytać istotę życia chrześcijańskiego. Nie dziwi zatem to, że papież Benedykt XVI tak często w swoim nauczaniu podejmował temat Eucharystii. Chciał w ten sposób pogłębić i ożywić u ludzi wierzących kult Jezusa Eucharystycznego. W swoim nauczaniu ukazywał Eucharystię jako największy skarb dany człowiekowi w celu kształtowania życia moralnego. Nieustannie przypominał o zobowiązaniach wynikających z uczestnictwa w Eucharystii. Przez swą specyfikę Eucharystia zawiera bowiem w sobie wezwania moralne: do postawy ofiarnej, do karmienia się chlebem życia, do uwielbienia i dziękczynienia oraz do życia wiarą i miłością. Wypełnianie w codzienności wszystkich tych postaw i wezwań moralnych jest drogą do postępu w życiu eucharystycznym. 


\section{Slowa kluczowe}

Benedykt XVI, Eucharystia, Kościół, życie moralne, ofiara, uczta, uwielbienie, dziękczynienie, tajemnica wiary i miłości

\section{Keywords}

Benedict XVI, Eucharist, Church, moral life, sacrifice, feast, worship, thanksgiving, mystery of faith and love

\section{Bibliography}

Antoniewicz M., Chrystologiczno-sakramentalne podstawy ,mistyki” Eucharystii w ,Deus caritas est” Benedykta XVI, "Poznańskie Studia Teologiczne” 23 (2009), p. 103-113.

Benedict XVI, The Church is an organism, not an organisation (St Paul and the Sacraments). General Audience (Vatican City - 10 December 2008), "L'Osservatore Romano" (English edition) 30 (2009) 2, pp. 50-52.

Benedykt XVI, Adhortacja apostolska ,, Sacramentum caritatis”, Tarnów 2007.

Benedykt XVI, Adhortacja apostolska ,,Verbum Domini”, Kraków 2010.

Benedykt XVI, Adoracja najlepszym przygotowaniem do komunii eucharystycznej. Przemówienie do uczestników sesji plenarnej Kongregacji ds. Kultu Bożego i Dyscypliny Sakramentów (Watykan — 13 marca 2009), "L'Osservatore Romano" (Polish edition) 30 (2009) 5, pp. 49-51.

Benedykt XVI, Celebrujac Eucharystie, kapłani toruja droge modlitwie współczesnych ludzi. Homilia podczas Mszy świętej Krzyżma w Wielki Czwartek (Watykan 9 kwietnia 2009), “L’Osservatore Romano” (Polish edition) 30 (2009) 6, pp. 18-20.

Benedykt XVI, Chleb, który prawdziwie zaspokaja głód człowieka. Rozważanie przed modlitwa „Aniot Pański” (Castel Gandolfo — 29 lipca 2012), “L'Osservatore Romano" (Polish edition) 33 (2012) 9-10, pp. 49-50.

Benedykt XVI, Chrystus Głowa Ciała - Kościoła i władca wszechświata (Św. Paweł a Kościół Chrystusowy). Audiencja generalna (Watykan — 14 stycznia 2009), "L'Osservatore Romano" (Polish edition) 30 (2009) 3, pp. 34-37.

Benedykt XVI, Chrześcijaństwo jest przede wszystkim darem. Homilia podczas Mszy świętej Wieczerzy Pańskiej (Watykan — 20 marca 2008), "L'Osservatore Romano" (Polish edition) 29 (2008) 5, pp. 8-10.

Benedykt XVI, Dar komunii. Audiencja generalna (Watykan — 29 marca 2006), "L'Osservatore Romano" (Polish edition) 27 (2006) 8, pp. 35-36.

Benedykt XVI, Encyklika „, Caritas in veritate”, Tarnów 2009.

Benedykt XVI, Encyklika „Deus caritas est”, Kraków 2006.

Benedykt XVI, Encyklika ,, Spe salvi”, Tarnów 2007. 
Benedykt XVI, Eucharystia darem Boga dla życia świata. Homilia podczas Mszy świętej na zakończenie 49. Międzynarodowego Kongresu Eucharystycznego w Quebecu (Watykan - 22 czerwca 2008), "L’Osservatore Romano" (Polish edition) 29 (2008) 7-8, pp. 22-24.

Benedykt XVI, Eucharystia i miłość. Rozważanie przed modlitwa „, Anioł Pański” (Watykan — 25 września 2005), “L’Osservatore Romano" (Polish edition) 27 (2006) 1, pp. 55-56.

Benedykt XVI, Eucharystia jest tajemnica wielkiej bliskości i komunii każdego człowieka z Panem. Homilia podczas mszy świętej Wieczerzy Pańskiej (Watykan 21 kwietnia 2011), "L’Osservatore Romano" (Polish edition) 32 (2011) 6, pp. 34-36.

Benedykt XVI, Eucharystia musi być centrum waszego życia. Homilia podczas Mszy świętej na zakończenie Światowego Dnia Młodzieży (Watykan - 21 sierpnia 2005), "L’Osservatore Romano" (Polish edition) 26 (2005) 10, pp. 26-28.

Benedykt XVI, Eucharystia największym naszym darem. Przemówienie do przedstawicieli środowisk akademickich Rzymu (Watykan — 14 grudnia 2006), "L'Osservatore Romano" (Polish edition) 28 (2007) 2, p. 37.

Benedykt XVI, Eucharystia otwarta na wszystkich jest prawdziwym miejscem jedności. Przemówienie do wspólnoty Drogi Neokatechumenalnej (Watykan — 20 stycznia 2012), "L’Osservatore Romano" (Polish edition) 33 (2012) 3, pp. 17-18.

Benedykt XVI, Eucharystia skarbem Kościoła. Rozważanie przed modlitwa ,, Anioł Pański” (Castel Gandolfo — 4 września 2005), "L’Osservatore Romano” (Polish edition) 26 (2005) 10, pp. 50-51.

Benedykt XVI, Eucharystia szkoła miłości i solidarności. Rozważanie przed modlitwa „Aniot Pański” (Watykan — 25 maja 2008), "L'Osservatore Romano” (Polish edition) 29 (2008) 7-8, p. 42.

Benedykt XVI, Jezus z Nazaretu, cz. I: Od chrztu w Jordanie do Przemienienia, thum. W. Szymona, Kraków 2011.

Benedykt XVI, Jezus z Nazaretu, cz. II: Od wjazdu do Jerozolimy do Zmartwychwstania, tłum. W. Szymona, Kielce 2011.

Benedykt XVI, Krzyż Chrystusa przemienit kult starotestamentalny (Św. Pawel a kult sprawowany przez chrześcijan). Audiencja generalna (Watykan — 7 stycznia 2009), "L’Osservatore Romano" (Polish edition) 30 (2009) 3, pp. 32-34.

Benedykt XVI, List apostolski „Porta fidei”, Kraków 2012.

Benedykt XVI, Nasze drogi niech będa drogami Jezusa. Homilia podczas Mszy świętej w uroczystość Najświętszego Ciała i Krwi Chrystusa (Watykan — 26 maja 2005), "L'Osservatore Romano" (Polish edition) 26 (2005) 7-8, pp. 23-24.

Benedykt XVI, Niech Kongres będzie dla was owocnym doświadczeniem komunii z Chrystusem. Przesłanie na 50. Międzynarodowy Kongres Eucharystyczny w Dublinie (Watykan — 17 czerwca 2012), "L'Osservatore Romano" (Polish edition) 33 (2012) 7-8, pp. 41-42. 
Benedykt XVI, Odnówmy wiarę w rzeczywista obecność Chrystusa w Eucharystii. Homilia podczas Mszy świętej w uroczystość Najświętszego Ciała i Krwi Pańskiej (Watykan - 11 czerwca 2009), "L’Osservatore Romano” (Polish edition) 30 (2009) 10, pp. 10-11.

Benedykt XVI, Pan Jezus idzie ulicami Rzymu. Homilia podczas Mszy świętej w uroczystość Najświętszego Ciała i Krwi Chrystusa (Watykan - 7 czerwca 2007), "L’Osservatore Romano" (Polish edition) 28 (2007) 7-8, pp. 39-40.

Benedykt XVI, Paweł Apostoł Narodów, Częstochowa 2008.

Benedykt XVI, Pochylmy się przed Bogiem, który pochylit się nad nami. Homilia podczas Mszy świętej w uroczystość Bożego Ciała (Watykan — 22 maja 2008), "L’Osservatore Romano" (Polish edition) 29 (2008) 6, pp. 48-50.

Benedykt XVI, Pokarm, który wzmacnia zmęczonych i zagubionych. Audiencja generalna (Watykan - 11 stycznia 2012), "L'Osservatore Romano" (Polish edition) 33 (2012) 3, pp. 29-31.

Benedykt XVI, Psalm 116 b-dziękczynienie w świątyni. Audiencja generalna (Watykan — 25 maja 2005), "L'Osservatore Romano" (Polish edition) 26 (2005) 7-8, pp. $28-29$.

Benedykt XVI, ,Sacramentum caritatis” źródłem radości chrześcijańskiej. Rozważanie przed modlitwa „Anioł Pański” (Watykan — 18 marca 2007), “L'Osservatore Romano" (Polish edition) 28 (2007) 5, pp. 54-55.

Benedykt XVI, Światłość świata. W rozmowie z Peterem Seewaldem, tłum. P. Napiwodzki, Kraków 2011.

Benedykt XVI, Święto Eucharystii, bez której Kościót nie może istnieć. Rozważanie przed modlitwa „Anioł Pański” (Watykan — 26 czerwca 2011), "L'Osservatore Romano" (Polish edition) 32 (2011) 8-9, pp. 49-50.

Benedykt XVI, W Eucharystii Chrystus żyje wśród nas i dla nas. Homilia podczas Mszy świętej na zakończenie XXIV Kongresu Eucharystycznego we Włoszech (Bari 29 maja 2005), "L’Osservatore Romano” (Polish edition) 26 (2005) 9, pp. 8-10.

Benedykt XVI, Zmartwychwstały Chrystus idzie pośród nas. Homilia podczas Mszy świętej w uroczystość Bożego Ciała (Watykan - 23 czerwca 2011), "L'Osservatore Romano" (Polish edition) 32 (2011) 8-9, pp. 31-32.

Benedykt XVI, Żyjmy moca Eucharystii. Homilia podczas Mszy świętej z okazji inauguracji Synodu (Watykan - 2 października 2005), "L'Osservatore Romano" (Polish edition) 27 (2006) 1, pp. 7-8.

Bołoz W., Moralne zobowiąanie Eucharystii, "Homo Dei” 55 (1986) 1, pp. 175-180.

Charytański J., Eucharystia centrum życia chrześcijańskiego, “Ateneum Kapłańskie” 75 (1983) 101, pp. 392-397.

Franciszek, Encyklika „Laudato Si,”, Kraków 2015.

Franciszek, Encyklika „Lumen fidei”, Kraków 2013.

Jan Paweł II, Encyklika „Ecclesia de Eucharistia”, Tarnów 2003. 
Jan Paweł II, List apostolski „Dominicae coenae” [in:] Wybór listów Ojca Świętego Jana Pawła II, t. 1, Kraków 1997, pp. 3-30.

Jeżyna K., Eucharystia [in:] Jan Paweł II, Encyklopedia nauczania moralnego, red. J. Nagórny, K. Jeżyna, Radom 2005, pp. 188-195.

Katechizm Kościoła Katolickiego, Poznań 1994.

Michalik A., Zrozumieć chrześcijaństwo. Istota chrześcijaństwa według Josepha Ratzingera, Tarnów 2008.

Nagórny J., Eucharystia - we wspólnocie i dla wspólnoty [in:] Eucharystia - miłość i dziękczynienie. Homo meditans IX, red. W. Słomka, A.J. Nowak, Lublin 1992, pp. 123-140.

Nowak A.J., Eucharystia znaczy dziękczynienie [in:] Eucharystia - miłość i dziękczynienie..., pp. 53-74.

Pałęcki W., Eucharystia w świetle teologii misteriów i posynodalnej adhortacji „, Sacramentum caritatis" papieża Benedykta XVI, "Liturgia Sacra” 14 (2008) 2, pp. 343361.

Papieska Komisja Teologiczna, Biblia a moralność. Biblijne korzenie postępowania chrześcijańskiego, tłum. R. Rubinkiewicz, Kielce 2009.

Perz A., Wpływ Eucharystii na życie chrześcijanina, "Kieleckie Studia Teologiczne" 5 (2006), pp. 123-133.

Ratzinger J., Teologia liturgii. Sakramentalne podstawy życia chrześcijańskiego. Opera omnia. T. XI, thum. W. Szymona, Lublin 2012.

Sobór Watykański II, Dekret o posłudze i życiu prezbiterów „Presbyterorum ordinis” [in:] Sobór Watykański II, Konstytucje. Dekrety. Deklaracje, Poznań 2008, pp. 747-805.

Sobór Watykański II, Konstytucja o liturgii świętej „,Sacrosanctum concilium” [in:] Sobór Watykański II, Konstytucje..., pp. 48-107.

Suwiński S., Wychowanie dziecka do życia Eucharystia, "Ateneum Kapłańskie" 584 (2006) 147, pp. 61-72.

Sylwanowicz A., Eucharystia w teologii liturgii Benedykta XVI, "Studia Loviciensia" 15 (2013), s. 93-105.

Szymik J., Theologia Benedicta, vol. 2, Katowice 2016.

Wojtczak A., Społeczne konsekwencje Eucharystii wedtug adhortacji apostolskiej Benedykta XVI „, Sacramentum caritatis”, “Liturgia Sacra” 13 (2007) 1, pp. 73-90.

Żurek A., „Mysterium passionis — corpus et sanguis Christi — communio”. Eucharystia sakramentem wtajemniczenia chrześcijańskiego w Kościele łacińskim czwartego i początku piątego wieku, Katowice 2012. 